\title{
Synthesis and Spectral Characterization of Lanthanide Complexes Derived from 2-[(4-bromo-2,6-dichloro- phenylimino)-methyl]-4,6-diiodo-phenol
}

\author{
V.R. RAJEWAR ${ }^{1}$, M.K.DHARMALE ${ }^{2}$ and S.R. PINGALKAR ${ }^{1}$ \\ 1Department of Chemistry N.E.S.Science College, Nanded, India. \\ ${ }^{2}$ Department of Chemistry Yeshwant Mahavidyalaya, Nanded, India. \\ *Corresponding author E-mail : dharmalevaishu@ rediffmail.com
} http://dx.doi.org/10.13005/ojc/300471

(Received: July 28, 2014; Accepted: September 22, 2014)

\begin{abstract}
The solid complexes of $\mathrm{La}(\mathrm{III}), \operatorname{Pr}(\mathrm{III}), \mathrm{Tb}(\mathrm{III}), \mathrm{Sm}(\mathrm{III})$ and $\mathrm{Nd}(\mathrm{III})$ were prepared from bidentate Schiff base, 2-[(4-bromo-2,6-dichloro-phenylimino)-methyl]-4,6-diiodo-phenol. The Schiff base ligand was synthesized from 3,5 diiodosalicylaldehyde and 4-bromo-2,6-dichlorobenzenamine. These metal complexes were characterized by molar conductivity, magnetic susceptibility, thermal analysis, X-ray diffraction, FTIR, ${ }^{1} \mathrm{H}$-NMR and UV-Vis. The analytical data of these metal complexes showed metal:ligand ratio of 1:2 $\mathrm{La}(\mathrm{III}), \operatorname{Pr}(\mathrm{III}), \mathrm{Tb}(\mathrm{III}), \mathrm{Sm}(\mathrm{III})$ and 1:1 for $\mathrm{Nd}$ (III) complexes. The physico-chemical study supports the presence of octahedral geometry around $\mathrm{La}(\mathrm{III}), \operatorname{Pr}(\mathrm{III})$, $\mathrm{Tb}(\mathrm{III}), \mathrm{Sm}$ (III) and $\mathrm{Nd}(\mathrm{III})$ ions. The IR spectral data reveal that the ligand behaves as bidentate with ON donor atom sequence towards central metal ion. The molar conductance values of metal complexes suggest their electrolyte nature except $\mathrm{Nd}$ (III) complex. The X-ray diffraction data suggest monoclinic crystal system for $\operatorname{Pr}$ (III), Nd (III) complexes. Thermal behavior (TG/DTA) shows breakdown of complexes.
\end{abstract}

Key words: Bidentate Schiff base, Metal complexes, Thermal analysis. XRD,

\section{INTRODUCTION}

Schiff bases derived from aromatic amines and aldehydes have a wide variety and an important class of ligands in coordination chemistry and find extensive applications in different fields, e.g., biological, inorganic and analytical chemistry ${ }^{1.2}$. Many biologically important Schiff bases have been reported in the literature possessing, antimicrobial, antibacterial, antifungal, anti-inflammatory, antitumor and anti HIV activities ${ }^{3.4}$. Schiff bases play important roles in coordination chemistry as they easily form stable complexes with most transition metal ions ${ }^{5}$.

The interaction of these donors ligands and metal ions give complexes of different geometries and these complexes are potentially biologically active ${ }^{6}$. Several research papers reported the synthesis and characterization of 
transition metal complexes of Schiff bases derived from salicylaldehyde ${ }^{7,8}$.

Metal complexes with Schiff base ligands containing salicylaldehyde and its derivatives; have been extensively studied. Metal complexes with such ligands are quite common and also reflect their facile synthesis, accessibility of diverse structural modifications and wide applications in different fields, such as catalysis, biological systems and material chemistry ${ }^{9,10}$.

Transition metal complexes with Schiff base as ligand have been amongst the widely studied co-ordination compounds in the past few years, since they are found to be widely applicable in many fields such as biochemical, analytical and antimicrobial fields ${ }^{11-15}$. It is well known from the literature that much work have been done on the synthesis and characterization of this compounds ${ }^{16-}$ 18 with Schiff base ligand formed from salicylaldehyde or substituted salicylaldehyde and various aromatic amines ${ }^{19-23}$.

Salicylaldehyde is called 2hydroxybenzaldehyde and ortho-hydroxy benzaldehyde and is an organic compound with the formula $\mathrm{C}_{7} \mathrm{H}_{6} \mathrm{O}_{2}$. Part of the class hydroxy aromatic aldehydes, aromatic nucleus contains two functional groups: a hydroxyl and aldehyde one. This colorless liquid has a bitter almond odor at higher concentrations The natural oils found in Spiraea [Filipendula (Spiraea) ulmaria (Rosaceae)].

Sweet-smelling flowers containing salicylaldehyde and methyl salicylate, glycosides form. Was also identified as a component of the characteristic flavor of buckwheat. ${ }^{24}$ Salicilaldehyde is used as an important intermediate in the chemical industry, in medicine. It is used in perfume, fragrances, dyes, pharmaceuticals, etc. ${ }^{25}$ Salicylaldehyde and its derivatives can be used as preservatives in cosmetic products, ${ }^{26}$ fragrances, essential oils in various biological applications. ${ }^{27}$ Also get in formulation of perfumes and fragrances. Salicylic aldehyde is an important intermediate in the manufacture of herbicides and pesticides. ${ }^{28}$ Also, salicylaldehyde and its derivatives are used for various reactions for the production of polymers and fibers.

\section{EXPERIMENTAL}

All chemicals and solvents are used AR grade. All the metals were used as their chloride salts. UV spectra recorded on UV-vis spectrophotometer 119. Conductance or metal complex was determined in DMSO on conductivity meter quiptronics model NO-EQ665. Melting points were recorded on in recorded by open capillary method and are uncorreded. $\mathrm{H}^{1}$-NMR spectra or a Schiff base and its metal complex recorded on Brukcer $300 \mathrm{MHz}$ spectrometer in DMSO. Elemental analysis was carried out on Eager 350 analyser. Magnetic measurement were done on solid complexes using Guoy method. Powder XRD pattern of complexes are recorded Philips Analytical XRD B.V. at CFC Shivaji University Kolhapur.

\section{Synthesis of ligand}

Synthesis of 2-[(4-Bromo-2,6-DichloroPhenylimino)- Methyl]-4,6-Diiodo-Phenol (BDPDP) Schiff base

Schiff base ligand were synthesized by refluxing of 3,5 diiodosalicylaldehyde $(0.01 \mathrm{M})$ and 4-bromo-2,6-dichlorobenzenamine $(0.01 \mathrm{M})$ in $50 \mathrm{~m} 1$ ethanol on water bath for 4-5 hours in presence of 2-3 drops of glacial acetic acid. The reaction mixture was kept for overnight, where yellow color precipitate was obtained. It was filtered by whatmann paper, washed with distilled water then alcohol, dried in vacuum dessicator. Pure Schiff base was recrystallized from ethanol. The purity of ligand was checked by TLC.

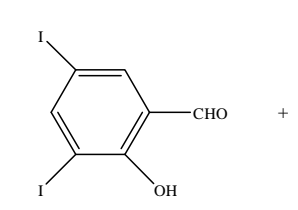

3,5 diiodosalicylaldehyde

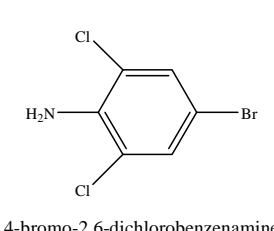

4-bromo-2,6-dichlorobenzenamin

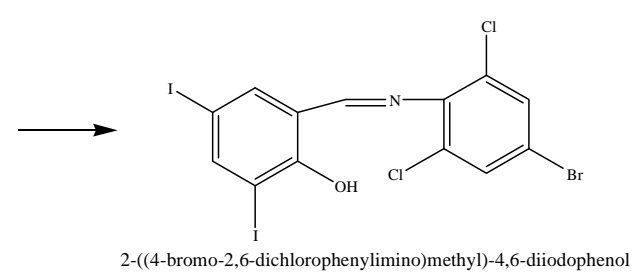


Synthesis of metal Complexes

The ethanolic solution of Metal chloride $(0.01 \mathrm{M})$ was added to hot ethanolic solution of BDPDP (0.02 M) La(III), Pr (III), Tb(III) ,Sm(III) and $(0.01 \mathrm{M})$ in $\mathrm{Nd}(\mathrm{III})$ complexes drop wise with constant stirring. $\mathrm{PH}$ of the reaction mixture was adjusted to $7-7.2$ with alcoholic ammonia solution. Resulting reaction mixture refluxed for 5 to 6 hours on water bath.

Colored complexes was allowed to digest and collected by filtration. Then washed with sufficient quantity of distilled water and little hot ethanol to apparent dryness and dried in vacuum desiccators.

\section{RESULTS AND DISCUSSION}

\section{Physical and analytical parameters}

Empirical formulae of the complexes were deduced on the basis of elemental analysis, metal ligand ratio and thermal analysis (table No. 1.1 and 1.2). Complexes possess different colors, metal complexes of ligand BDPDP are insoluble in common organic solvents, dissolve freely in DMSO/ DMF High melting points of complexes suggest that

Table 1: Physical and analytical data of BDPDP metal complexes

\begin{tabular}{|c|c|c|c|c|c|c|c|c|}
\hline Compound & F.W. & Yield & $\begin{array}{l}\text { M.L } \\
\text { ratio }\end{array}$ & $\begin{array}{c}\text { M.P. } \\
\text { decom. } \\
\text { Temp }^{\circ} \mathrm{C}\end{array}$ & Color & $\begin{array}{c}\text { Molar } \\
\text { Conductance } \\
\mathbf{W}^{-1} \mathrm{~cm}^{2} \\
\mathrm{~mol}^{-1}\end{array}$ & $\begin{array}{c}\text { \%of Cl } \\
\text { cal. } \\
\text { (obs) }\end{array}$ & $\begin{array}{c}\text { Magnetic } \\
\text { Moment }\end{array}$ \\
\hline BDPDP(L) & 596.81 & $67 \%$ & - & $190^{\circ} \mathrm{C}$ & Yellow & - & - & - \\
\hline$\left[\mathrm{La}(\mathrm{L})_{2} 2 \mathrm{H}_{2} \mathrm{O}\right] \mathrm{Cl}$ & 1404.01 & $58 \%$ & $1: 2$ & $>270{ }^{\circ} \mathrm{C}$ & $\begin{array}{l}\text { Muddy } \\
\text { Yellow }\end{array}$ & 66 & $\begin{array}{c}12.63 \\
(12.59)\end{array}$ & Dimagnetc \\
\hline$\left[\mathrm{Pr}(\mathrm{L})_{2} 2 \mathrm{H}_{2} \mathrm{O}\right] \mathrm{Cl}$ & 1408.03 & $62 \%$ & $1: 2$ & $>270{ }^{\circ} \mathrm{C}$ & Brown & 71 & $\begin{array}{c}12.59 \\
(12.57)\end{array}$ & $\begin{array}{l}\text { Param- } \\
\text { agnetic }\end{array}$ \\
\hline$\left[\mathrm{Nd}(\mathrm{L})_{1} 2 \mathrm{H}_{2} \mathrm{O} 2 \mathrm{Cl}\right]$ & 847.99 & $58 \%$ & $1: 1$ & $>270{ }^{\circ} \mathrm{C}$ & Grey & 14 & $\begin{array}{c}16.72 \\
(16.74)\end{array}$ & $\begin{array}{l}\text { Param- } \\
\text { agnetic }\end{array}$ \\
\hline$\left[\mathrm{Tb}(\mathrm{L})_{2} 2 \mathrm{H}_{2} \mathrm{O}\right] \mathrm{Cl}$ & 1426.05 & $51 \%$ & $1: 2$ & $>270{ }^{\circ} \mathrm{C}$ & $\begin{array}{c}\text { Dark } \\
\text { Yellow }\end{array}$ & 78 & $\begin{array}{c}12.43 \\
(12.41)\end{array}$ & $\begin{array}{l}\text { Param- } \\
\text { agnetic }\end{array}$ \\
\hline$\left[\mathrm{Sm}(\mathrm{L})_{2} 2 \mathrm{H}_{2} \mathrm{O}\right] \mathrm{Cl}$ & 1412.33 & $61 \%$ & $1: 2$ & $>270^{\circ} \mathrm{C}$ & $\begin{array}{c}\text { Faint } \\
\text { Yellow }\end{array}$ & 64 & $\begin{array}{c}12.52 \\
(12.48)\end{array}$ & $\begin{array}{l}\text { Param- } \\
\text { agnetic }\end{array}$ \\
\hline
\end{tabular}

Table 2: Percent C, H, N,O and metal ion in BDPDP metal complexes

\begin{tabular}{|c|c|c|c|c|c|c|c|c|}
\hline Compound & Empirical Formula & $\begin{array}{l}\text { \%C obs } \\
\text { (calcd.) }\end{array}$ & $\begin{array}{l}\text { \%H obs } \\
\text { (calcd. }\end{array}$ & $\begin{array}{l}\text { \%N obs } \\
\text { (calcd.) }\end{array}$ & $\begin{array}{l}\text { \%O obs } \\
\text { (calcd. }\end{array}$ & $\begin{array}{l}\text { \% l obs } \\
\text { (calcd.) }\end{array}$ & & \\
\hline $\operatorname{BDPDP}(\mathrm{L})$ & $\mathrm{C}_{13} \mathrm{H}_{6} \mathrm{BrCl}_{2} \mathrm{I}_{2} \mathrm{NO}$ & $\begin{array}{c}26.16 \\
(26.12)\end{array}$ & $\begin{array}{c}1.01 \\
(0.92)\end{array}$ & $\begin{array}{c}2.35 \\
(2.24)\end{array}$ & $\begin{array}{c}2.68 \\
(2.46)\end{array}$ & $\begin{array}{c}42.53 \\
(42.42)\end{array}$ & $\begin{array}{c}13.39 \\
(13.12)\end{array}$ & - \\
\hline$\left[\mathrm{La}(\mathrm{L})_{2} 2 \mathrm{H}_{2} \mathrm{O}\right] \mathrm{Cl}$ & $\mathrm{C}_{26} \mathrm{H}_{16} \mathrm{Br}_{2} \mathrm{Cl}_{5} \mathrm{I}_{4} \mathrm{LaN}_{2} \mathrm{O}_{4}$ & $\begin{array}{c}22.24 \\
(22.14)\end{array}$ & $\begin{array}{c}1.15 \\
(1.11)\end{array}$ & $\begin{array}{c}2.00 \\
(1.98)\end{array}$ & $\begin{array}{c}4.56 \\
(4.31)\end{array}$ & $\begin{array}{c}36.15 \\
(36.23)\end{array}$ & $\begin{array}{c}11.38 \\
(11.23)\end{array}$ & $\begin{array}{c}9.89 \\
(9.78)\end{array}$ \\
\hline$\left[\mathrm{Pr}(\mathrm{L})_{2} 2 \mathrm{H}_{2} \mathrm{O}\right] \mathrm{Cl}$ & $\mathrm{C}_{26} \mathrm{H}_{18} \mathrm{Br}_{2} \mathrm{Cl}_{5} \mathrm{I}_{4} \mathrm{~N}_{2} \mathrm{O}_{4} \mathrm{Pr}$ & $\begin{array}{c}22.18 \\
(22.09)\end{array}$ & $\begin{array}{c}1.29 \\
(1.14)\end{array}$ & $\begin{array}{c}4.55 \\
(4.34)\end{array}$ & $\begin{array}{c}4.55 \\
(4.43)\end{array}$ & $\begin{array}{c}36.05 \\
(35.95)\end{array}$ & $\begin{array}{c}11.35 \\
(11.27)\end{array}$ & $\begin{array}{c}10.01 \\
(9.67)\end{array}$ \\
\hline$\left[\mathrm{Nd}(\mathrm{L})_{1} 2 \mathrm{H}_{2} \mathrm{O} 2 \mathrm{Cl}\right]$ & $\mathrm{C}_{13} \mathrm{H}_{10} \mathrm{BrCl}_{4} \mathrm{I}_{2} \mathrm{NNdO}_{3}$ & $\begin{array}{c}18.41 \\
(18.31)\end{array}$ & $\begin{array}{c}1.19 \\
(1.04)\end{array}$ & $\begin{array}{c}1.65 \\
(1.45)\end{array}$ & $\begin{array}{c}5.66 \\
(5.45)\end{array}$ & $\begin{array}{c}29.93 \\
(29.84)\end{array}$ & $\begin{array}{c}9.42 \\
(9.31)\end{array}$ & $\begin{array}{c}17.01 \\
(16.47)\end{array}$ \\
\hline$\left[\mathrm{Tb}(\mathrm{L})_{2} 2 \mathrm{H}_{2} \mathrm{O}\right] \mathrm{Cl}$ & $\mathrm{C}_{26} \mathrm{H}_{18} \mathrm{Br}_{2} \mathrm{Cl}_{5} \mathrm{I}_{4} \mathrm{~N}_{2} \mathrm{O}_{4} \mathrm{~Tb}$ & $\begin{array}{c}21,90 \\
(21.87)\end{array}$ & $\begin{array}{c}1.27 \\
(1.16)\end{array}$ & $\begin{array}{c}1.96 \\
(1.89)\end{array}$ & $\begin{array}{c}4.49 \\
(4.38)\end{array}$ & $\begin{array}{c}35.60 \\
(35.49)\end{array}$ & $\begin{array}{c}11.21 \\
(11.14)\end{array}$ & $\begin{array}{c}11.14 \\
(11.03)\end{array}$ \\
\hline$\left[\mathrm{Sm}(\mathrm{L})_{2} 2 \mathrm{H}_{2} \mathrm{O}\right] \mathrm{Cl}$ & $\mathrm{C}_{26} \mathrm{H}_{16} \mathrm{Br}_{2} \mathrm{Cl}_{5} \mathrm{I}_{4} \mathrm{~N}_{2} \mathrm{O}_{4} \mathrm{Sm}$ & $\begin{array}{c}22.06 \\
(21.89)\end{array}$ & $\begin{array}{c}1.14 \\
(1.08)\end{array}$ & $\begin{array}{c}1.98 \\
(1.78)\end{array}$ & $\begin{array}{c}4.52 \\
(4.43)\end{array}$ & $\begin{array}{c}35.86 \\
(35.73)\end{array}$ & $\begin{array}{c}11.29 \\
(11.18)\end{array}$ & $\begin{array}{c}10.62 \\
(10.54)\end{array}$ \\
\hline
\end{tabular}


Table 1.3: Electronic spectral data of BDPDP complexes

\begin{tabular}{lccc}
\hline Ligand $/$ Complex & Absorbance $\mathbf{n m}$ & $\mathbf{n} / \mathbf{c m}^{-1}$ & Transition \\
\hline $\mathrm{BDPDP}(\mathrm{L})$ & 293 & 34160 & $\pi-\pi^{*}$ \\
{$\left[\mathrm{La}(\mathrm{L})_{2} 2 \mathrm{H}_{2} \mathrm{O}\right] \mathrm{Cl}_{3}$} & 261 & 38314 & $\pi-\pi^{\star}$ \\
& 431 & 23201 & $\mathrm{LMCT}$ \\
{$\left[\mathrm{Pr}(\mathrm{L})_{2} 2 \mathrm{H}_{2} \mathrm{O}\right] \mathrm{Cl}$} & 261 & 38314 & $\pi-\pi^{\star}$ \\
& 431 & 23201 & $\mathrm{LMCT}$ \\
{$\left[\mathrm{Nd}(\mathrm{L})_{1} 2 \mathrm{H}_{2} \mathrm{O} \mathrm{Cl}\right]$} & 259 & 38610 & $\pi-\pi^{*}$ \\
{$\left[\mathrm{~Tb}(\mathrm{~L})_{2} 2 \mathrm{H}_{2} \mathrm{O}\right] \mathrm{Cl}$} & 431 & 23201 & $\mathrm{LMCT}$ \\
{$\left[\mathrm{Sm}(\mathrm{L})_{2} 2 \mathrm{H}_{2} \mathrm{O}\right] \mathrm{Cl}$} & 261 & 38314 & $\pi-\pi^{\star}$ \\
& 429 & 23310 & $\mathrm{LMCT}$ \\
& 261 & 38314 & $\pi-\pi^{\star}$ \\
& 429 & 23310 & $\mathrm{LMCT}$ \\
\hline
\end{tabular}

Table 4: Infrared spectral data of the ligand (DPMDI) and their La(III), $\operatorname{Pr}$ (III), Nd(III), Tb(III) and Sm(III) metal complexes

\begin{tabular}{lccccccc}
\hline Compound & $v(\mathrm{CH}=\mathrm{N})$ & $v(\mathbf{C}-\mathbf{O})$ & $v(\mathbf{M}-\mathbf{O})$ & $v(\mathbf{M}-\mathrm{N})$ & $v\left(\mathrm{H}_{2} \mathbf{O}\right)$ Rocking & $v\left(\mathbf{H}_{2} \mathbf{O}\right)$ & $v(\mathbf{O H})$ \\
\hline $\mathrm{BDPDP}(\mathrm{L})$ & 1616 & 1204 & - & - & - & - & 3447 \\
{$\left[\mathrm{La}(\mathrm{L})_{2} 2 \mathrm{H}_{2} \mathrm{O}\right] \mathrm{Cl}$} & 1596 & 1212 & 520 & 432 & 853 & 3134 & - \\
{$\left[\mathrm{Pr}(\mathrm{L})_{2} 2 \mathrm{H}_{2} \mathrm{O}\right] \mathrm{Cl}$} & 1627 & 1209 & 505 & 432 & 860 & 3477 & - \\
{$\left[\mathrm{Nd}(\mathrm{L})_{1} 2 \mathrm{H}_{2} \mathrm{O} 2 \mathrm{Cl}\right]$} & 1629 & 1211 & 507 & 435 & 869 & 3448 & - \\
{$\left[\mathrm{Tb}(\mathrm{L})_{2} 2 \mathrm{H}_{2} \mathrm{O}\right] \mathrm{Cl}$} & 1627 & 1211 & 507 & 441 & 889 & 3437 & - \\
{$\left[\mathrm{Sm}(\mathrm{L})_{2} 2 \mathrm{H}_{2} \mathrm{O}\right] \mathrm{Cl}$} & 1631 & 1211 & 509 & 435 & 867 & 3473 & - \\
\hline
\end{tabular}

Table 5: Thermal Analysis data for metal complexes

\begin{tabular}{|c|c|c|c|c|}
\hline \multirow[t]{2}{*}{ Complex } & \multirow{2}{*}{$\begin{array}{l}\text { Decomposition } \\
\text { Temp }^{\circ} \mathrm{C}\end{array}$} & \multirow[t]{2}{*}{ Lost fragment } & \multicolumn{2}{|c|}{ Weight loss \% } \\
\hline & & & Experimental & Theoretical \\
\hline \multirow[t]{6}{*}[\mathrm{Tb}(\mathrm{L})_{2}2\mathrm{H}_{2}\mathrm{O}]{$\mathrm{Cl}$} & $140^{\circ} \mathrm{C}$ & two coordinate water molecule & 2.44 & 2.56 \\
\hline & $140-280^{\circ} \mathrm{C}$ & one lattice chlorine & 2.42 & 2.53 \\
\hline & $280-310{ }^{\circ} \mathrm{C}$ & Four iodine & 38.04 & 36.22 \\
\hline & $310-600{ }^{\circ} \mathrm{C}$ & Four chlorine two bromine & 18.16 & 21.53 \\
\hline & $600-800{ }^{\circ} \mathrm{C}$ & Organic moiety & 28.12 & 27.23 \\
\hline & $800-1000{ }^{\circ} \mathrm{C}$ & Metal oxide & 12.44 & 13.04 \\
\hline \multirow[t]{4}{*}[\operatorname{Pr}(\mathrm{L})_{2}2\mathrm{H}_{2}\mathrm{O}]{$\mathrm{Cl}$} & $\begin{array}{l}160^{\circ} \mathrm{C} \\
160-390^{\circ} \mathrm{C}\end{array}$ & $\begin{array}{l}\text { two coordinated Water molecules } \\
\text { one lattice chloride molecules four }\end{array}$ & 2.32 & 2.60 \\
\hline & & iodine, four chloride, two bromine & 61.32 & 61.02 \\
\hline & $390-800{ }^{\circ} \mathrm{C}$ & Organic Moiety & 27.68 & 26.64 \\
\hline & $800-1000{ }^{\circ} \mathrm{C}$ & Metal oxide & 11.87 & 11.91 \\
\hline \multirow[t]{4}{*}[\mathrm{Nd}(\mathrm{L})_{1}2\mathrm{H}_{2}\mathrm{O}2\mathrm{Cl}]{} & $160{ }^{\circ} \mathrm{C}$ & coordinated two water molecules & 4.25 & 4.30 \\
\hline & $160-430{ }^{\circ} \mathrm{C}$ & Two iodine, One bromine & 36.71 & 39.89 \\
\hline & $430-800{ }^{\circ} \mathrm{C}$ & four chlorine, Organic moiety & 33.64 & 32.60 \\
\hline & $800-1000{ }^{\circ} \mathrm{C}$ & Metal oxide & 19.58 & 20.09 \\
\hline
\end{tabular}


complexes are stable at normal temperatures ${ }^{29}$ Molar conductivity (Im 71 to $82 \mathrm{~W}^{-1} \mathrm{~cm}^{2} \mathrm{~mol}^{-1}$ ) reveals electrolytic nature of the complexes ${ }^{30}$ except Neodymium metal ion complex $\left(\operatorname{Im~} 14 \mathrm{~W}^{-1} \mathrm{~cm}^{2} \mathrm{~mol}^{-1}\right)$ reveals nonelectrolytic nature of the complex.(table 1.1).

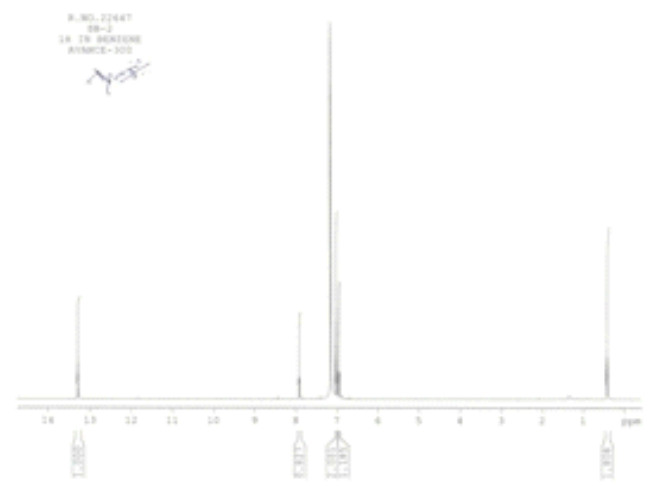

Fig. 1: ${ }^{1} \mathrm{H}$ NMR ligand BDPDP

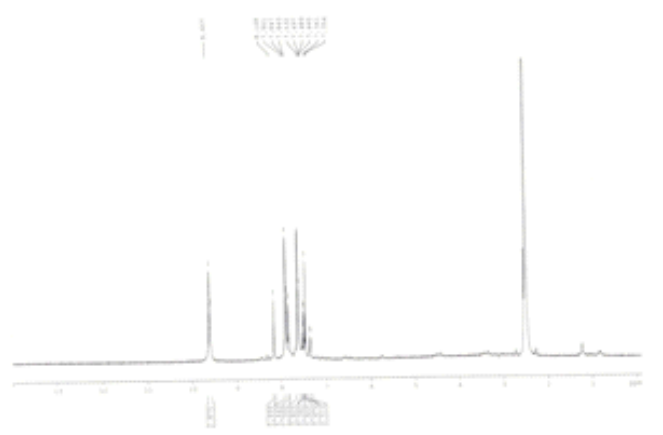

Fig. 2: ${ }^{1} \mathrm{H}$ NMR Metal complex

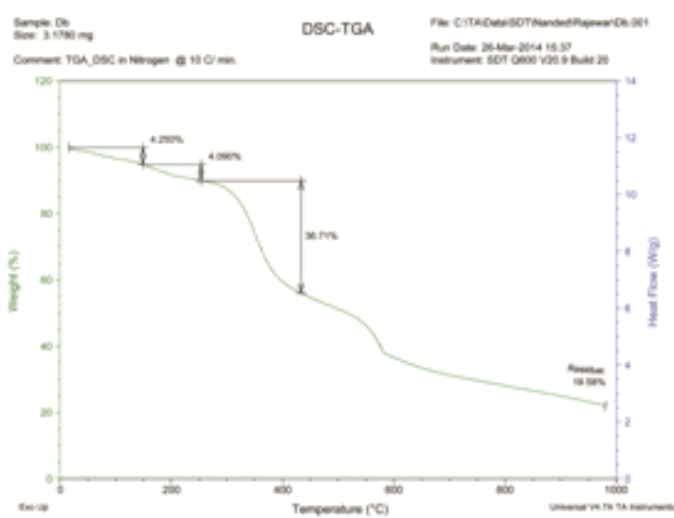

Fig. 4: TG/DSC [Nd(L) $\left.)_{1} 2 \mathrm{H}_{2} \mathrm{O} 2 \mathrm{Cl}\right]$

\section{Electronic spectra}

Plots of UV-Visible spectra of ligand BDPDP and its metal complexes were recorded on UV-Visible spectrophotometer 119-Pc based instrument are presented in figure 6.1, 6.2, 6.3, 6.4,6.5 and 6.6. Ligand (BDPDP) shows strong absorption band at $34160 \mathrm{~cm}^{-1}$ assigned for $p-p^{*}$ transition. Absorption bands and corresponding transition are given in the table No. 1.3.

The UV electronic spectra of $\mathrm{La}(\mathrm{III}), \operatorname{Pr}(\mathrm{III})$, $\mathrm{Nd}(\mathrm{III}), \mathrm{Tb}(\mathrm{III})$ and $\mathrm{Sm}(\mathrm{III})$ complexes have indicates absorption bands at $23201 \mathrm{~cm}^{-1}, 23201 \mathrm{~cm}^{-1}$, $23201 \mathrm{~cm}^{-1}, 23310 \mathrm{~cm}^{-1}$ and $23310 \mathrm{~cm}^{-1}$ assigned as charge transfer ${ }^{31,32}$.

\section{Infrared spectra}

Determination of coordinating atoms in the complex is made on the basis of comparison of IR spectra of the ligand and their metal complexes.

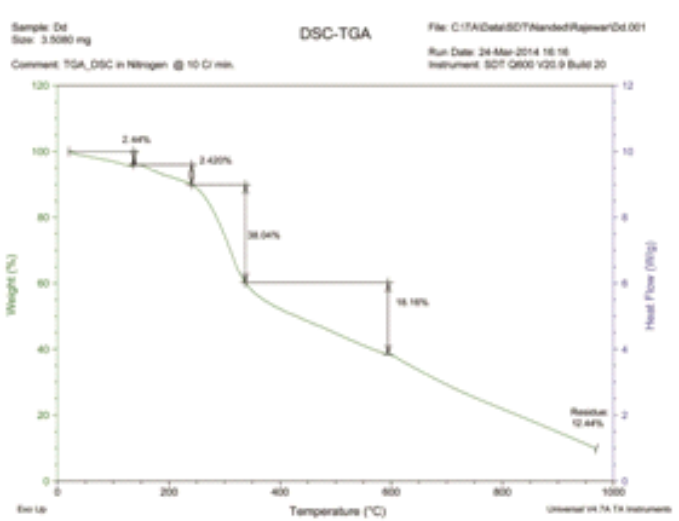

Fig. 3: TG/DSC [Tb(L) $\left.2 \mathrm{H}_{2} \mathrm{O}\right] \mathrm{Cl}$

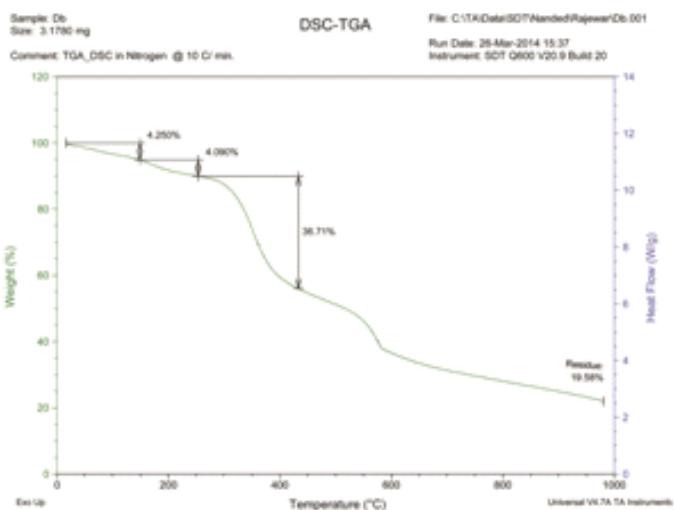

Fig. 5: TG/DSC $\left[\operatorname{Pr}\left(\mathrm{L}_{2} 2 \mathrm{H}_{2} \mathrm{O}\right] \mathrm{Cl}\right.$ 
Significant changes in wave numbers of the coordinating atoms involved in coordination are summarized in the table No. 1.4.

\section{IR spectral study of BDPDP Ligand}

Ligand BDPDP contains phenolic- $\mathrm{OH}$ and azomethine group. In spectra of ligand exhibits strong $v(\mathrm{O}-\mathrm{H})$ stretching at $3447 \mathrm{~cm}^{-1}$, corresponding to $\mathrm{n}(\mathrm{OH})$ of phenol. The band at $1204 \mathrm{~cm}^{-1}$ is due to presence of $v(\mathrm{C}-\mathrm{O})$ group. It also indicate $v(\mathrm{C}=\mathrm{N})$ stretching frequency at $1616 \mathrm{~cm}^{-1}$. On complexation significant changes in wave numbers are observed.

\section{IR spectral study of La(III) complex}

The IR spectra of Metal complexes is compared with IR spectra of ligand (BDPDP), there are certain shifts in the bands. In complex deprotonation of $-\mathrm{OH}$ in phenolic group and indicating involvement of phenolic group in coordination ${ }^{33}$. The band stretching vibration in ligand due to phenolic $\mathrm{n}(\mathrm{OH})$ group observed at $3447 \mathrm{~cm}^{-1}$, Which is disappear in complex.

Besides, ligand exhibits stretching of $v$ $(\mathrm{C}=\mathrm{N})$ stretching at $1616 \mathrm{~cm}^{-1}$ which on complexation shifted to lower wave number at 1596$1631 \mathrm{~cm}^{-1}$ suggesting that azomethine nitrogen are involved in coordination ${ }^{34-35}$. A new broad band at $3134-3477 \mathrm{~cm}^{-1}$ suggested the presence of coordinated water molecule ${ }^{36}$.

The appearance of new bands in the spectra of metal ion complex at $432-441 \mathrm{~cm}^{-1}$ and $505-520 \mathrm{~cm}^{-1}$ due to new bonding i.e. $v(M-N)$ and $v(\mathrm{M}-\mathrm{O})^{37,38}$.

Thus the ligand BDPDP exhibits uninegative bidentate behaviour and coordinates to the metal ion through azomethine nitrogen and phenoxide oxygen for $\mathrm{La}(\mathrm{III}), \operatorname{Pr}(\mathrm{III}), \mathrm{Tb}(\mathrm{III})$ and Sm(III)complexes, $\mathrm{Nd}(\mathrm{III})$ complex behave neutral in nature.

\section{${ }^{1} \mathrm{HNMR}$ Spectra}

${ }^{1} \mathrm{H}$ NMR spectral studies of ligand BDPDP indicated signals at $\mathrm{d}$ 6.9-7.2 ppm corresponding to aromatic protons $(\mathrm{m}, 4 \mathrm{H}, \mathrm{Ar}-\mathrm{H})$ and at d $7.9 \mathrm{ppm}$ due to azomethine group $(\mathrm{CH}=\mathrm{N})$. A strong signal at d $13.3 \mathrm{ppm}$ assignable $(\mathrm{S}, 1 \mathrm{H})$ due to phenolic
$\mathrm{OH}$ group (fig. 1.1).

In the metal complex signal corresponding to phenolic $\mathrm{OH}$ group at d $13.3 \mathrm{ppm}$ has disappeared ${ }^{39-41}$ (fig.1.2) may be attributed to deprotonation of $-\mathrm{OH}$ group on involvement of via $-\mathrm{OH}$ in bonding. A new peak due to presence of coordinated water at d $2.5 \mathrm{ppm}$ is observed in metal complex $^{42}$. The shift in azomethine group from d 7.9 $\mathrm{ppm}$ to $\mathrm{d} 9.6 \mathrm{ppm}$ indicate coordination through water molucule azomethine group.

Thus, BDPDP.molecule seems to be coordinated to the metal through phenoxide oxygen and azomethine group in $\operatorname{Pr}$ (III) metal complex.

\section{Thermal study}

$\mathrm{Nd}(\mathrm{III}), \operatorname{Pr}(\mathrm{III})$ and $\mathrm{Tb}(\mathrm{III})$ complexes were studied by therrnogravimetric analysis from ambident temperature to $1000^{\circ} \mathrm{C}$ in nitrogen atomosphere. The range of temperature, experimental and calculated mass losses of the decomposition reaction are given in the table No. 1.5. TGA/DSC scans are depicted in figures $1.3,1.4$ and 1.5 .

\section{Thermal study of $\left[\mathrm{Tb}(\mathrm{L})_{2} 2 \mathrm{H}_{2} \mathrm{O}\right] \mathrm{Cl}$}

The thermogram of $\mathrm{Tb}$ (III) complex shows weight loss $2.44 \%$ corresponding to two coordinated water molecule in the range from room temperature to $140^{\circ} \mathrm{C}$. Decomposition reaction corresponds to an experimental mass $2.42 \%$ occurs in the temperature range $140^{\circ} \mathrm{C}-280^{\circ} \mathrm{C}$ attributed loss of one lattice chlorine ${ }^{43}$. part of the complex.

In the temperature range $280^{\circ} \mathrm{C}-310^{\circ} \mathrm{C}$ Four iodine part is lost and this loss corresponds to $38.04 \%$. As the temperature increases to $310-600^{\circ} \mathrm{C}$ there is of $18.16 \%$ indicating loss of four chloride,two bromine, part of metal complex. From $600-800^{\circ} \mathrm{C}$ loss of organic moiety which is $28.12 \%$. Finally $800^{\circ} \mathrm{C}-1000^{\circ} \mathrm{C}$ residue is obtained corresponding to $\mathrm{Tb}_{2} \mathrm{O}_{3}$ as stable residue ${ }^{44} 12.44 \%$.

\section{Thermal study of $\left[\mathrm{Pr}(\mathrm{L})_{2} 2 \mathrm{H}_{2} \mathrm{O}\right] \mathrm{Cl}$}

The TGA of $\operatorname{Pr}($ III) complex indicates loss in weight in the range from room temperature to $160^{\circ} \mathrm{C}$ corresponding to $2.32 \%$ indicates the loss of coordinated water-molecule. 
Decomposition beyond this temperature in the range $160^{\circ} \mathrm{C}-390^{\circ} \mathrm{C}$ corresponds to mass loss of $61.32 \%$ in the TG curve assigned to expulsion of one lattice chloride molecules four iodine, four chloride, two bromine part of the complex. The decomposition occurs in the temperature $390^{\circ} \mathrm{C}$ $800^{\circ} \mathrm{C}$ indicates the loss of Organic Moiety 27.68 $\%$. Further at $800^{\circ} \mathrm{C}-1000^{\circ} \mathrm{C}$ losses of $11.87 \%$ were occurs indicating presence of thermally stable residual metal oxide ${ }^{45}$

\section{Thermal study of $\left[\mathrm{Nd}(\mathrm{L})_{1} 2 \mathrm{H}_{2} \mathrm{O} 2 \mathrm{Cl}\right]$}

TGA of Nd (III) complex shows weight loss corresponding to mass loss $4.25 \%$. This loss corresponds to loss of coordinated water molecule in the range from room temperature to $160^{\circ} \mathrm{C}^{46}$ Further decomposition at $160^{\circ} \mathrm{C}-430^{\circ} \mathrm{Closs}$ of $36.71 \%$ was occurs indicating loss of Two iodine, One bromine of the complex. From $430-800^{\circ} \mathrm{C}$ loss of four chlorine, Organic moiety which is 33.64 $\%$. The end product of decomposition is formation of $\mathrm{Nd}_{2} \mathrm{O}_{3}$ weight corresponds to 19.58 percent which is equal to theoretical value 20.09 .

\section{Powder x-ray studies}

$X$-ray diffractograms of the metal complexes were recorded in the $2 q$ range from 10 $90^{\circ}$ at a wave length of $1.5405 \mathrm{~A}^{\circ}$ and using $\mathrm{Cu} \mathrm{Ka}$ radiation source. Results of miller indices, lattice parameters and unit cell volume are computed from programmer. Data has been summarized in the following tables.

$\left[\mathrm{Nd}(\mathrm{L})_{1} 2 \mathrm{H}_{2} \mathrm{O} 2 \mathrm{Cl}\right]$

Crystal system: Monoclinic Lattice Type: $\mathbf{P}$

Lattice Parameter: $a=9.53034 \quad b=8.00951 \quad c=$ $7.79302 \mathrm{~A}^{0}$

Lattice Parameter: Alpha $=90.000$ Beta $=121.572$

Gama $=90.000$

\begin{tabular}{lcccccc}
$\mathbf{h}$ & $\mathbf{k}$ & $\mathbf{l}$ & $\boldsymbol{\theta}$ (cal) & $\boldsymbol{\theta}$ (Obs) & $\mathbf{d}$ (cal) & $\mathbf{d}$ (obs) \\
\hline-1 & 0 & 1 & 6.00366 & 6.01408 & 7.36480 & 7.34506 \\
-1 & 1 & 0 & 7.76464 & 7.75704 & 5.70152 & 5.70286 \\
-2 & 0 & 0 & 10.94017 & 10.92606 & 4.05882 & 4.06188 \\
-2 & 1 & 2 & 13.31070 & 13.30282 & 3.34576 & 3.34628 \\
-2 & 2 & 1 & 14.58616 & 14.57042 & 3.05874 & 3.06078 \\
-4 & 1 & 0 & 23.05168 & 23.04753 & 1.96725 & 1.96712 \\
3 & 0 & 2 & 26.85357 & 26.85035 & 1.70529 & 1.70514 \\
-4 & 2 & 5 & 32.39762 & 32.39613 & 1.43768 & 1.43751 \\
-1 & 5 & 3 & 34.86598 & 34.85211 & 1.34748 & 1.34775 \\
-2 & 6 & 1 & 36.83277 & 36.83274 & 1.28494 & 1.28477 \\
-2 & 1 & 6 & 38.73699 & 38.73415 & 1.23101 & 1.23093 \\
-4 & 3 & 6 & 41.28170 & 41.26937 & 1.16754 & 1.16769 \\
-4 & 6 & 3 & 42.69762 & 42.69542 & 1.13592 & 1.13584 \\
\hline
\end{tabular}

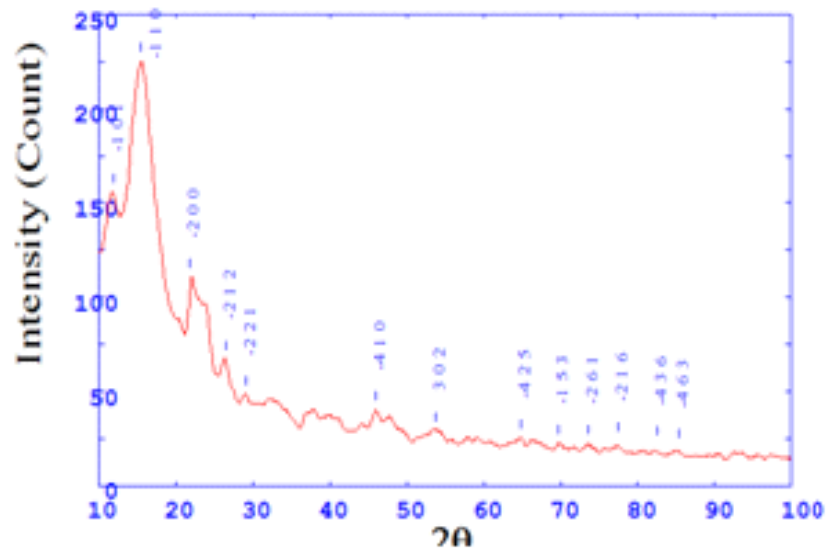


The cell data and crystal parameters of $\left[\mathrm{Nd}(\mathrm{L})_{1} 2 \mathrm{H}_{2} \mathrm{O} 2 \mathrm{Cl}\right]$ complex is given in the tables indicates that complex have monoclinic crystal system ${ }^{47}$, with lattice type-P.

$\left[\mathrm{Pr}(\mathrm{L})_{2} 2 \mathrm{H}_{2} \mathrm{O}\right] \mathrm{Cl}$

Crystal system: Monoclinic Lattice Type: $\mathbf{P}$ Lattice Parameter: $a=19.06907 \quad b=4.64343 \quad c=$

\section{$7.04556 \mathrm{~A}^{0}$}

Lattice Parameter: Alpha $=90.000$ Beta $=108.476$ Gama $=90.000$

Cell data and crystal lattice parameters of $\left[\operatorname{Pr}(\mathrm{L})_{2} 2 \mathrm{H}_{2} \mathrm{O}\right] \mathrm{Cl}$ complex attributed to monoclinic crystal system ${ }^{48}$, with lattice type-P.

\begin{tabular}{lcccccc}
\hline $\mathbf{h}$ & $\mathbf{k}$ & $\mathbf{l}$ & $\boldsymbol{\theta}$, (cal) & $\boldsymbol{\theta}$ (Obs) & $\mathbf{d}(\mathbf{c a l})$ & $\mathbf{d}$ (obs) \\
\hline-2 & 0 & 1 & 6.87288 & 6.88556 & 1.27114 & 6.43274 \\
1 & 0 & 1 & 7.75612 & 7.75704 & 5.70775 & 5.71298 \\
2 & 0 & 1 & 9.41625 & 9.42077 & 4.70827 & 4.71002 \\
-1 & 1 & 1 & 11.46505 & 11.48063 & 3.87533 & 3.87282 \\
1 & 1 & 1 & 12.34822 & 12.35211 & 3.60201 & 3.60321 \\
1 & 0 & 2 & 14.32149 & 14.33275 & 3.11405 & 3.11337 \\
-7 & 0 & 2 & 18.28842 & 18.29401 & 2.45474 & 2.45506 \\
0 & 2 & 2 & 23.82950 & 23.83979 & 1.90660 & 1.90644 \\
8 & 1 & 2 & 29.77117 & 29.78169 & 1.55134 & 1.55123 \\
0 & 3 & 3 & 37.30260 & 37.30810 & 1.27107 & 1.27114 \\
\hline
\end{tabular}

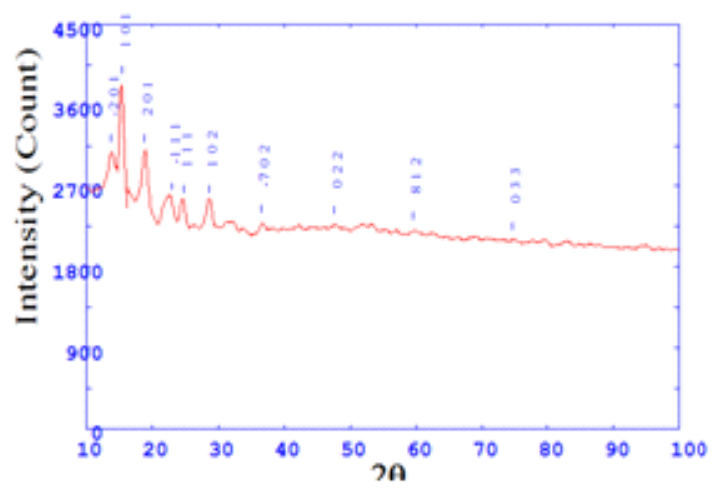

\section{Proposed structures of the chelates}

Based on above result probable structure have been proposed

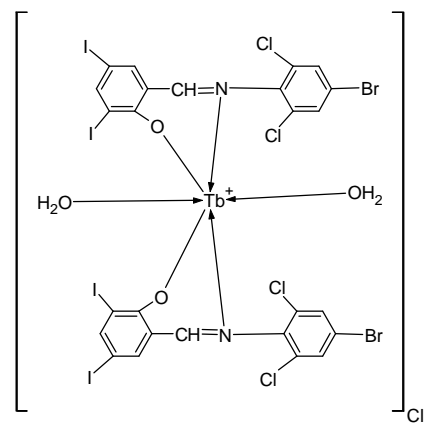

$\mathrm{Tb}(\mathrm{L})_{2} 2 \mathrm{H}_{2} \mathrm{O} \mathrm{Cl}$

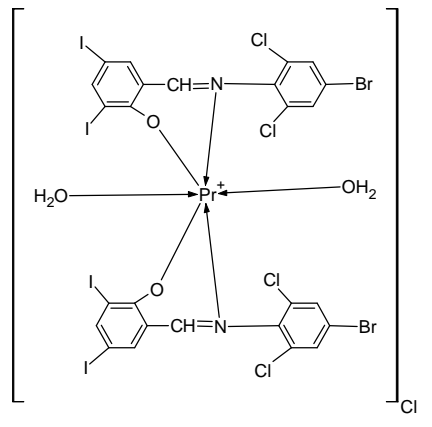

$\left[\operatorname{Pr}(\mathrm{L})_{2} 2 \mathrm{H}_{2} \mathrm{O}\right] \mathrm{Cl}$

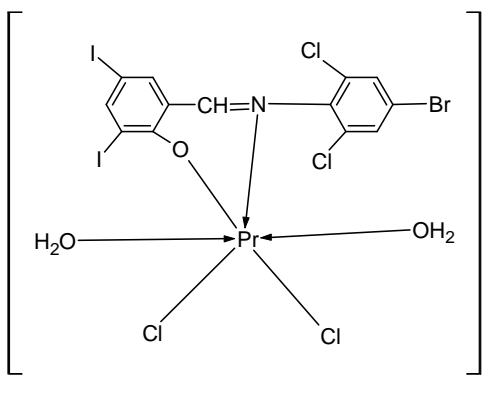

$\left[\mathrm{Nd}(\mathrm{L}){ }_{1} 2 \mathrm{H}_{2} \mathrm{O} 2 \mathrm{Cl}\right]$ 


\section{REFERENCES}

1. Raman N, Muthuraj V, Ravichandran S, Kulandaisamy A., Synthesis, characterisation and electrochemical behaviour of $\mathrm{Cu}(\mathrm{II}), \mathrm{Co}(\mathrm{II}), \mathrm{Ni}(\mathrm{II})$ and $\mathrm{Zn}(\mathrm{II})$ complexes derived from acetylacetone and $p$-anisidine and their antimicrobial activity. Journal of Chemical Sciences, 2003, 115(3): 161-167.

2. Hughes, M. N., "The inorganic chemistry of biological Processes", 2nd ed., Wiley, New York, 1984.

3. Pandeya S.N., Sriram D., Nath G. and Clercq E. De, Synthesis, antibacterial, antifungal and antiviral activity evaluation of some new bis- Schiff bases of isatin and their derivatives,Pharm. Acta Helv.1999, 74: 11.

4. Pandeya S.N., Sriram D., Nath G. and Clercq E. de, Synthesis, antibacterial, antifungal and anti- HIV evaluation of Schiff and Mannich bases of isatin and its derivatives with triazole, Arzneimittel Forsch, , 2000, 50: 55

5. Spinu C., Pleniceanu M. and Tigae C., Biologically Active Transition Metal Chelates with a 2-Thiophenecarboxaldehyde Derived Schiff Base: Synthesis, Characterization, and Antibacterial Properties, Turk. J. Chem., 2008, 32: 487.

6. Harlal S. and Varshney A. K., "Synthetic structural and biochemical studies of organotin (IV) with Schiff bases having nitrogen and sulfur donor ligands", bioinorganic chemistry and applications, Article ID 23245:1-7, 2006.

7. Chaurasia M. R., Miss Prema S. and Singh N. K., "Mixed ligand complexes of N-6-methyl benzothiazol-2-yl-salicylaldimine and 2methylbenzimidazole with $\mathrm{Cu}(\mathrm{II}), \mathrm{Ni}(\mathrm{II})$, $\mathrm{Co}(\mathrm{II}), \mathrm{Mn}(\mathrm{II}), \mathrm{VO}(\mathrm{II}), \mathrm{Zn}(\mathrm{II}), \mathrm{Cd}(\mathrm{II})$ and $\mathrm{Hg}(\mathrm{II})$, 1982, 74, 123-128.

8. Shayma A. Shaker, Yang F., Abbas A. S., Synthesis and Characterization of Mixed Ligand Complexes of 8-Hydroxy-quinoline and 0 -hydroxybenz-ylidene-1-phenyl-2,3dimethyl - 4-amino-3-pyrazolin -5-on with $\mathrm{Fe}(\mathrm{II}), \mathrm{Co}(\mathrm{II}), \mathrm{Ni}(\mathrm{II})$ and $\mathrm{Cu}(\mathrm{II})$ ions, European Journal of Scientific Research, 2009, 33 (4), 702-709.
9. Iqbal, J., Tirmizi, S. A., and Watto, F. H., Biological properties of chloro-salicylidene aniline and its complexes with $\mathrm{Co}(\mathrm{II})$ and $\mathrm{Ni}(\mathrm{II})$. Turk J. Biol., 2006, 30, 1-4.

10. Bagihalli, G. B., Patil, S. A., and Badami, P. S., Synthesis, physicochemical investigation and biological studies of $\mathrm{Zn}$ (II) complexes with 1,2,4-triazole Schiff bases. J. Iran Chem. Soc., 2009, 6, 259-270.

11. N.L.Wengnack, H.M. Hoard and F. Rusnak, J. Am. Chem., 1999, 121, 9748.

12. N.H. Bhausar, B.D. Mistry and K.R. Desai, Asian J. Chem., 1999, 11, 65.

13. M.R. Maurya, Co.ord. Chem. Rev., 2003, 237,163.

14. G.D. Whitener, J.R. Hagadorn and Amold, J, Chem., Soc. Dalton Trans, 1999, 8, 1249.

15. M.M. Patel and K.C. Patel, J. Indian Chem. Soc., 1997, 1, 74.

16. A.K. Usha and S. Chandra, Synth. React. Inorg. Met.-Org. Chem., 1992, 2, 1565.

17. B.S. Garg and L. Kapur, Inorg.Chim.Acta, 1990, 173, 223.

18. Z.H. Chohan and S. Kausar, Chem. Pharm. Bull., (Japan) 1993, 41, 951.

19. R.H.Holm, G.W. Everett and A. Chakravorty, Prog. Inorg. Chem., 1966, 7, 83.

20. L. Sacconi, Coord. Chem. Rev., 1966, 1, 126, 192.

21. M. Akbar Ali and S. E. Livingstone, Coord. Chem. Rev., 1970, 3,101.

22. A.V. Ablov, N.I. Belichuk and L.N. Nazhelskaya, Russ. J. Inorg. Chem., 1972, 17, 226 .

23. M.D. Hobday and T.D. Smith., Coord. Chem. Rev., 1973, 9, 311.

24. Janeš D.; Kreft S., "Salicylaldehyde is a characteristic aroma component of buckwheat groats", Food Chemistry, 2008, 109(2), 293-298.

25. Simmonds J., Robinson G. K., "Formation of Benzaldehyde by Pseudomonas putida ATCC 12633", Appl. Microbial Biotechnol, 1998, 50, 353-358.

26. Genta M.T., Villa C., Mariani E., Loupy A., Petit A., Rizzetto R., Mascarotti A., Morini F., Ferro M., " Microwave-assisted preparation 
of cyclic ketals from a cineole ketone as potential cosmetic ingredients: solvent-free synthesis, odour evaluation, in vitro cytotoxicity and antimicrobial assays", Int. J. Pharm., 2002, 231, 11-20.

27. Mounika K, Anupama B., Pragathi J.,Gyanakumari C., "Synthesis, Characterization and Biological Activity of a Schiff Base Derived from 3-Ethoxy Salicylaldehyde and 2-Amino Benzoic acid and its Transition Metal Complexes", J. Sci. Res., 2010, 2(3)., 513-524.

28. Yildiz M., Dulger B., Koyuncu S.Y., Yapici B.M., "Synthesis and antimicrobial activity of bis(imido) Schiff bases derived from thiosemicarbazide with some 2hydroxyaldehydes and metal complexes", $J$. Indian Chem. Soc, 2004, 81, 7-12.

29. Rosu, T., Pahontu, E., Maxim, C., Georgescu, R., Stanica, N., Gulea, A., Polyhedron, 2011, 30(1), 154.

30. Reddy, P.R. and Reddy, A.M., I.J.Chem., 2002, 41A, 2083.

31. Pandey, R.N. and Nag, A.K., Rasayan J. Chem., 2009, 2(4), p. 990.

32. Abdullah, B.H., Asian Journal of Chemistry, 2007, 19(5), 3903.

33. Thirumagal, B., Malik, S. and Balasubramaniam, A., The Pharmacist, 2008, 3(1).

34. Kriza, A., Parnau, C., Popu. N. and Rosu, T., Analele Universitatii din Bucuresti Chimie, Anul XIII (Serienoua), 2004, 1-2, 179.

35. Subudhi, B.B., Panda, P.K., Bhatta, D., Jena, A., Iranian Journal of Pharmaceutical
Sciences Spring, 2009, 5(2), 83.

36. Canpolat, E. and Kaya, M., Transition Metal Chemistry, 2004, 29, p.550.

37. Malik, S., Ghosh, S. and Jain, B., Arch. Apll. Sci. Res., 2(2), 2010, p. 304.

38. Mruthyunjayaswamy, B.H.M., ljare, O.B. and Jadegoud, Y., J. Braz. Chem. Soc., 2005, 16(4), 783.

39. Nakamoto, K., Infrared spectra of inorganic and coordination compounds. John Wiely, New York, 1968.

40. Halli, M.B., Qureshi, Z.S., Vittal, P., Jumanal, B.N. and Patil, V.B., J. Ind. Council. Chem., 2008, 25(1), 1.

41. Reddy, V., Patil, N. and Patil, B.R., J. Ind. Council. Chem., 2006, 23(2), 1.

42. Pingalkar, S.R. and Deshpande, M.N., Orient. J. Chem., 2007, 23(1), 265.

43. Lakshmi, B., Shivananda, K.N., Gouda, A.P., Reddy, K., Rama, K. and Mahendra, K.N., Bull Korean Chem. Soc., 2011, 32(5).

44. Nishide, T., Journal of Materials Sciences, 2000, 35, 465.

45. Yaul, S.R., Yaul, A.R., Pethe, G.B. and Aswar, A.S., American-Eurasian Journal of Scientific Research, 2009, 4(4), 229.

46. RevanaSiddapa, H.D., Vijaya, B., Shiva Kiimar, L. and Pmsad, K.S., World Journal of Chemistry 2010, 5(1), p.18.

47. Gigant, K., Rammal, A. and Henry, M., J. Am. Chem. Soc., 2001, 123, 11632.

48. Gendler, S., Segal, S., Goldberg, I., Goldschmidt, Z. and Kol, M., Inorg. Chem., 2006, 45(12), 4783. 